\title{
Analisis sudut panel solar cell terhadap daya output dan efisiensi yang dihasilkan
}

\author{
Yano Hurung Anoi ${ }^{*}$, Ahmad Yani ${ }^{2}$, Yunanri W. ${ }^{3}$ \\ Prodi Teknik Mesin Sekolah Tinggi Teknologi Industri Bontang ${ }^{1,2}$ \\ Jl. Bridjend Katamso No. 40 Bontang-Kaltim 75311 \\ Prodi Teknik Informatika Universitas Teknologi Sumbawa ${ }^{3}$ \\ JI. Raya Olat Maras, Batu Alang Sumbawa Besar - NTB \\ Email: yanodayak@yahoo.com¹, yanibima@gmail.com², yunanri.w@uts.ac.id ${ }^{3}$
}

\begin{abstract}
One of the natural potentials as a source of electrical energy is solar energy. The sun is the main energy source for most of the processes that occur on the surface of the earth. Solar radiation received by the earth's surface is a fundamental input for many aspects, mainly an important parameter in the application of solar cells as electricity generation. Sun cells are devices that can convert sunlight into electrical energy. In this study the data collection of solar cell panel data is collected which includes the solar radiation data, the voltage data generated and the electric current data generated at each variation of the tilt angle $0^{\circ}, 8^{\circ}$, and $16^{\circ}$. This study aims to discover the effect of changes in the slope angle of solar cell panels on the efficiency of solar power generation systems. The study method used is an experimental development method which is carried out by using the tilt angle variation of the solar panel. The angle used by taking the tilt angle of the solar panel on the negative $x$-axis which aims to find the maximum tilt angle value. From the test results of 50 Watt Peak (WP) solar power plant installation, it can be concluded that the highest efficiency occurs at an angle of $16^{\circ}$ and at 09:00 with a value of $46.076 \%$, then the second occurs at an angle of 80 and at 09:00 with a value of 45,052\%, then the lowest efficiency occurs at a slope angle of $0^{\circ}$ and at 09:00 with a value of 43,986\%.
\end{abstract}

Keywords: Angles, 50 WP panel, solar cell, power output, \& efficiency.

\begin{abstract}
Abstrak
Salah satu potensi alam sebagai sumber energi listrik adalah energi tenaga matahari. Matahari merupakan sumber energi utama bagi sebagian besar proses-proses yang terjadi dipermukaan bumi. Radiasi matahari yang diterima permukaan bumi merupakan masukan fundamental untuk banyak aspek terutama merupakan parameter penting dalam aplikasi solar sel sebagi pembangkit listrik. Sel matahari merupakan piranti yang dapat mengkonversi cahaya matahari menjadi energi listrik. Pada penelitian ini dilakukan pengambilan data keluaran panel sel surya yang meliputi dara radiasi matahari, data tegangan yang dihasilkan dan data arus listrik yang dihasilkan pada tiap variasi sudut kemiringan $0^{\circ}, 8^{\circ}$, dan $16^{\circ}$. Tujuan dari penelitian ini adalah untuk mengetahui pengaruh perubahan sudut kemiringan panel solar cell terhadap efisiensi sistem pembangkit listrik tenaga surya. Metode penelitian yang digunakan adalah metode eksperimen pengembangan yang dilakukan adalah dengan menggunakan variasi sudut kemiringan panel surya. Sudut yang digunakan dengan mengambil sudut kemiringan panel surya pada sumbu $\mathrm{x}$ negatif yang tujuanya untuk mengetahui nilai sudut kemiringan yang maksimal. Dari hasil pengujian instalasi pembangkit listrik tenaga surya kapasitas 50 Watt Peak (WP) dapat diambil kesimpulan bahwa efisiensi tertinggi terjadi pada sudut kemiringan $16^{\circ}$ dan pada jam 09:00 dengan nilai sebesar 46.076 $\%$, kemudian yang kedua terjadi pada sudut kemiringan $8^{\circ}$ dan pada jam 09:00 dengan nilai
\end{abstract}


sebesar $45.052 \%$, kemudian efisiensi terendah terjadi pada sudut kemiringan $0^{\circ}$ dan pada jam 09:00 dengan nilai sebesar $43.986 \%$.

Kata kunci: Sudut, panel 50 WP, solar cell, daya output, \& efisiensi.

\section{Pendahuluan}

Matahari merupakan sumber energy yang bersih dan ramah lingkungan. Energi ini sangat cocok digunakan pada negara tropis seperti di Indonesia, karena letak geografis Indonesia yang berada di atas garis katulistiwa maka Indonesia memiliki potensi energi surya yang sangat besar. Setiap hari, di Indonesia dapat diperoleh energi sebesar 4,8-6,0 $\mathrm{kWh} / \mathrm{m} 2$ pada bidang horizontal yang tidak terlindung. Energi ini dapat dimanfaatkan secara langsung maupun segara tidak langsung [1].

Pemenuhan kebutuhan energi listrik saat ini masih bergantung pada sumber energi fosil yang ketersediaanya terbatas. Oleh karena itu dimasa mendatang pemanfaatan sumber energi terbarukan merupakan alternatif yang perlu terus dikembangkan [2].

Pemanfaatan energi listrik yang berasal dari matahari juga dapat dilakukan menggunakan efek photovoltaic, efek photovoltaic ini digunakan dalam sebuah solar cell yang terdiri dari susunan semiconductors untuk menghasilkan energy listrik [3]. Namun sayangnya solar cell yang kita gunakan masih memiliki daya yang kecil dibandingkan dengan biaya pembelian yang relative mahal, apalagi jika solar cell tersebut menggunakan sudut pemasangan yang konstan (tetap) [3].

Penggunaan panel surya dapat membangkitkan energi listrik dengan menggunakan energi sinar matahari. Panel surya yang terpasang selama ini masih bersifat statis, bearah pada satu orientasi. Dengan kondisi ini maka panel surya tidak dapat menangkap pancaran sinar matahari secara maksimal sepanjang hari, akibatnya efisiensi energi listrik yang dibangkitkan tidak maksimal [4].

\section{Tinjauan Pustaka}

\section{Prinsip kerja solar cells (photovoltaic)}

Energi solar atau radiasi cahaya terdiri dari biasan foton-foton yang memiliki tingkat energi yang berbedabeda. Perbedaan tingkat energi dari foton yang menentukan panjang gelombang dari spectrum cahaya. Ketika foton mengenai suatu sel photovoltaic, maka foton tersebut dapat dibiaskan dan diserap kemudian diteruskaan menembus sel photovoltaic. Foton yang diserap oleh sel photovoltaic inilah yang akan memicu timbulnya energi listrik [5].

Pada siang hari modul surya/panel solar cell menerima cahaya matahari yang kemudian diubah menjadi listrik melalui proses photovoltaic. Energi listrik yang dihasilkan oleh modul surya dapat langsung disalurkan ke beban atau disimpan dalam baterai sebelum digunakan ke beban. Dan arus searah DC (direct current) yang dihasilkan dari modul surya yang telah tersimpan dalam baterai sebelum digunakan ke beban terlebih dahulu. Ilustrasi prinsip kerja solar cell sebagaimana ditunjukkan pada gambar $1[5]$.

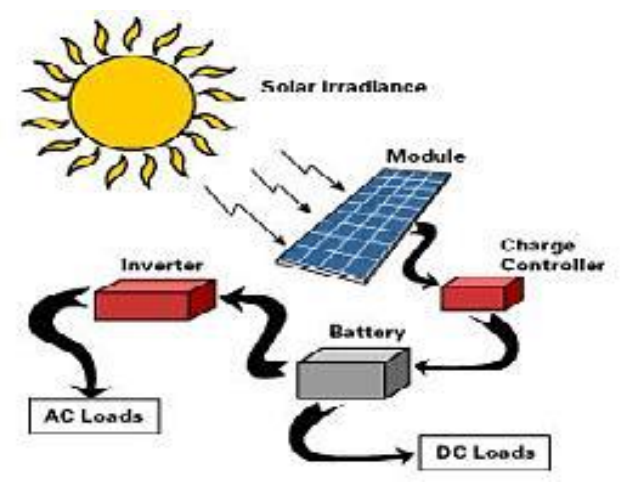

Gambar 1. Konsep kerja solar cell [5].

\section{Karakteristik panel fotovoltaik}

Sifat-sifat listrik dari modul surya biasanya diwakili oleh karakteristik arus tegangannya. Jika sebuah modul surya dihubung singkat $\left(\mathrm{V}_{\text {modul }}=0\right)$, maka arus 
hubung singkat $\left(\mathrm{I}_{\mathrm{sc}}\right)$ mengalir. Pada keadaan rangkaian terbuka $\left(\mathrm{I}_{\text {modul }}=0\right)$, maka tegangan modul disebut tegangan terbuka $\left(\mathrm{V}_{\text {oc }}\right)$.[6]

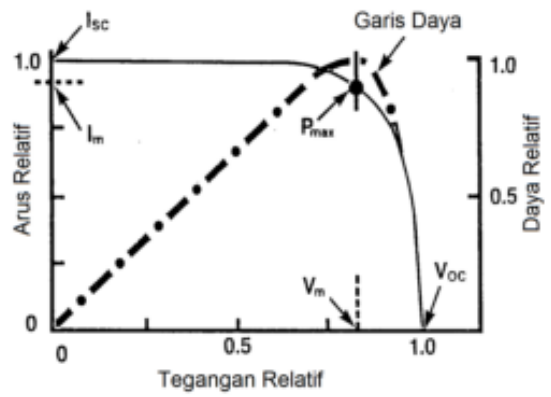

Gambar 2. Kurva Arus-Tegangan [6].

Daya yang dihasilkan modul surya, adalah sama dengan hasil kali arus dan tegangan yang dihasilkan oleh modul surya. Persamaan daya sebagaimana ditunjukkan pada persamaan 1 [3].

$$
P=V x I
$$

Dengan:

$$
\begin{aligned}
& \mathrm{P}=\text { Daya keluaran modul }(\text { Watt }) \\
& \mathrm{V}=\text { Tegangan kerja modul (Volt) } \\
& \mathrm{I}=\text { Arus kerja modul (Ampere) }
\end{aligned}
$$

Persamaan untuk menghitung efisiensi solar cell adalah:

$$
\eta=\frac{P_{\text {output }}}{P_{\text {input }}} \times 100 \%
$$

Dengan:

(Watt)

$$
\begin{array}{ll}
\eta & =\text { Efisiensi solar cell }(\%) \\
\mathrm{P}_{\text {output }} & =\text { Daya output modul }
\end{array}
$$

$$
\mathrm{P}_{\text {input }}=\text { Daya input }(\text { Watt })
$$

\section{Metode Penelitian}

Metode penelitian yang digunakan pada penelitian ini adalah studi literatur dan eksperimen pengembangan. Studi literatur digunakan untuk mengetahui dasar-dasar teori tentang panel surya, bagaimana prinsip kerjanya hingga bagaimana pengaruh sudut kemiringan panel surya terhadap daya listrik yang dihasilkan. Metode eksperimen pengembangan yang dilakukan adalah dengan menggunakan variasi sudut kemiringan panel surya. Sudut yang digunakan dengan mengambil sudut kemiringan panel surya pada sumbu $\mathrm{x}$ negatif yang tujuanya untuk mengetahui nilai sudut kemiringan yang maksimal [4].

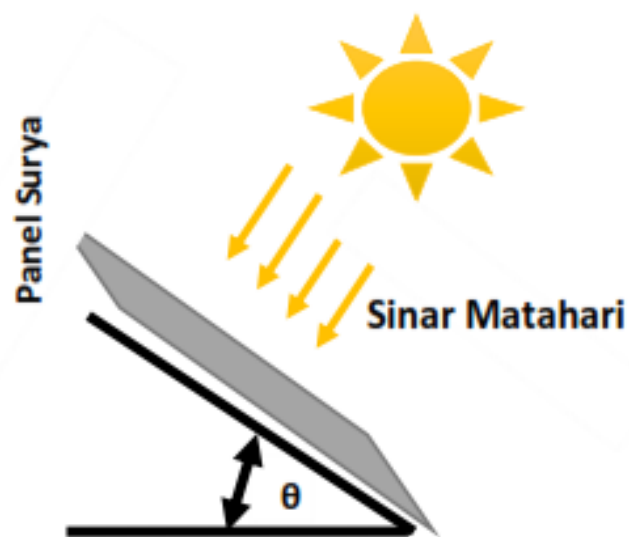

Gambar 3. Skema optimasi sudut kemiringan panel surya

Pengambilan data pada penelitian ini setiap hari cuaca cerah dari jam 09.00 16.00 WIT. Variabel bebas yang ditetapkan dalam penelitian ini adalah: sudut kemiringan panel $50 \mathrm{WP}$ yaitu sudut $0^{\circ}, 8^{\circ}$, dan $16^{\circ}$. Sedangakan variabel terikat yang diamati dalam penelitian ini adalahd aya ouput dan efisiensi solar cell. Alat dan bahan yang digunakan dalam penelitian ini adalah:

1. Panel PV $50 \mathrm{WP}$

2. Solar Power Meter

3. Multimeter Digital

4. Inverter

5. Busur Derajat

6. Baterai atau Aki

7. Charge controller

8. Kabel

Parameter yang diamati pada pengujian sistem pembangkit listrik tenaga surya kapasitas 50 WP meliputi pengukuran besaran secara berkala antara pukul 09:00 - 16:00 WIB dan setiap satu jam sekali dilihat pada alat ukur yang digunakan pada pengujian dan mencatatn nilai dari hasil pengukuran. Penggunaan alat ukur perlu diperhatikan dari jenis dan kegunaannya seperti yang digunakan pada pengujian sistem pembangkit listrik tenaga surya kapasitas $50 \mathrm{WP}$, alat ukur yang digunakan berupa Solar Power Meter yang berfungsi untuk mengukur radiasi matahari, Amperemeter digital yang 
berfungsi untuk mengukur arus dan voltmeter digital yang berfungsi untuk mengukur tegangan.

Ada beberapa prosedur yang harus diperhatikan pada pengujian sistem pembangkit listrik tenaga surya berkapasitas 50 WP diantaranya:

1. Memeriksa dan mengamati ketelitian dan kecermatan alat ukur yang digunakan pada pengujian.

2. Mencatan data-data hasil pengukuran pada tabel yang disediakan dari alat ukur yang digunakan dalam pengujian, alat ukur yang digunakan berupa Solar Power Meter, Voltmeter digital, dan Amperemeter digital.

3. Setelah data-data dari hasil pengujian terkumpul, langkah selanjutnya adalah pengolahan data.

Pada penelitian ini dilakukan pengambilan data keluaran panel sel surya yang meliputi dara radiasi matahari, data tegangan yang dihasilkan dan data arus listrik yang dihasilkan pada tiap variasi sudut kemiringan $0^{\circ}, 8^{\circ}$, dan $16^{\circ}$. Sedangkan teknik analisa data menggunakan teknik deskriptif berdasarkan hasil penelitian. Data yang diperoleh dari hasil pengamatan berupa data tegangan dan arus listrik serta data radiasi matahari, kemudian akan dilakukan pengolahan dengan rumus daya input dan daya output untuk mendapatkan nilai efisiensi sisitem pembangkit listrik tenaga surya. Dari hasil pengolahan tersebut kemudian akan dianalisis dan selanjutnya data akan di sajikan dalam bentuk tabel untuk menbuat grafik dengan bantuan komputer untuk menampilkan grafik daya output dan efisiensi sisitem pembangkit listrik tenaga surya.

\section{Hasil dan Pembahasan}

Pada penelitian ini dilakukan pengambilan data tegangan panel solar cell dan radiasi matahari. Dari penelitian yang dilakukan yaitu melakukan pengujian terhadap efisiensi panel 50 WP maka diperoleh data penelitian seperti ditunjukkan pada Tabel 1, 2, dan 3.

Tabel 1. Data hasil pengujian sudut $0^{\circ}$

\begin{tabular}{ccccc}
\hline $\begin{array}{c}\text { Waktu } \\
\text { Pengukura } \\
\mathrm{n}\end{array}$ & $\begin{array}{c}\text { Radiasi } \\
\text { Matahari }\end{array}$ & $\begin{array}{c}\text { Tega } \\
\text { ngan }\end{array}$ & $\begin{array}{c}\text { Arus } \\
\text { Listri } \\
\mathrm{k}\end{array}$ & $\begin{array}{c}\text { Kapasi } \\
\text { tas } \\
\text { Panel }\end{array}$ \\
\hline Jam & $\mathrm{W} / \mathrm{m}^{2}$ & Volt & $\mathrm{A}$ & (WP) \\
\hline $09: 00$ & 582 & 20.48 & 0.45 & 50 \\
\hline $10: 00$ & 792 & 20.51 & 0.46 & 50 \\
\hline $11: 00$ & 1102 & 20.55 & 0.47 & 50 \\
\hline $12: 00$ & 1460 & 20.58 & 0.48 & 50 \\
\hline $13: 00$ & 1331 & 20.56 & 0.46 & 50 \\
\hline $14: 00$ & 1043 & 20.52 & 0.45 & 50 \\
\hline $15: 00$ & 688 & 20.51 & 0.44 & 50 \\
\hline $16: 00$ & 548 & 20.47 & 0.43 & 50 \\
\hline
\end{tabular}

Tabel 2. Data hasil pengujian sudut $8^{\circ}$

\begin{tabular}{ccccc}
\hline $\begin{array}{c}\text { Waktu } \\
\text { Penguku } \\
\text { ran }\end{array}$ & $\begin{array}{c}\text { Radiasi } \\
\text { Matahari }\end{array}$ & $\begin{array}{c}\text { Tegang } \\
\text { an }\end{array}$ & $\begin{array}{c}\text { Arus } \\
\text { Listr } \\
\text { ik }\end{array}$ & $\begin{array}{c}\text { Kapas } \\
\text { itas } \\
\text { Panel }\end{array}$ \\
\hline Jam & $\mathrm{W} / \mathrm{m}^{2}$ & Volt & A & (WP) \\
\hline $09: 00$ & 582 & 20.52 & 0.46 & 50 \\
\hline $10: 00$ & 792 & 20.56 & 0.47 & 50 \\
\hline $11: 00$ & 1102 & 20.61 & 0.48 & 50 \\
\hline $12: 00$ & 1460 & 20.63 & 0.49 & 50 \\
\hline $13: 00$ & 1331 & 20.62 & 0.48 & 50 \\
\hline $14: 00$ & 1043 & 20.58 & 0.46 & 50 \\
\hline $15: 00$ & 688 & 20.52 & 0.45 & 50 \\
\hline $16: 00$ & 548 & 20.48 & 0.44 & 50 \\
\hline
\end{tabular}

Tabel 3. Data hasil pengujian sudut $16^{\circ}$

\begin{tabular}{ccccc}
$\begin{array}{c}\text { Waktu } \\
\text { Pengukuran }\end{array}$ & $\begin{array}{c}\text { Radiasi } \\
\text { Matahari }\end{array}$ & $\begin{array}{c}\text { Tega } \\
\text { ngan }\end{array}$ & $\begin{array}{c}\text { Arus } \\
\text { Listr } \\
\text { ik }\end{array}$ & $\begin{array}{c}\text { Kapas } \\
\text { itas } \\
\text { Panel }\end{array}$ \\
\hline Jam & $\mathrm{W} / \mathrm{m}^{2}$ & Volt & A & $(\mathrm{WP})$ \\
\hline $09: 00$ & 582 & 20.54 & 0.47 & 50 \\
\hline $10: 00$ & 792 & 20.58 & 0.48 & 50 \\
\hline $11: 00$ & 1102 & 20.62 & 0.49 & 50 \\
\hline $12: 00$ & 1460 & 20.66 & 0.50 & 50 \\
\hline $13: 00$ & 1331 & 20.64 & 0.49 & 50 \\
\hline $14: 00$ & 1043 & 20.61 & 0.47 & 50 \\
\hline $15: 00$ & 688 & 20.55 & 0.46 & 50 \\
\hline $16: 00$ & 548 & 20.53 & 0.45 & 50 \\
\hline
\end{tabular}

Dari data di atas kemudian dilakukan pengolahan data untuk mendapatkan efisiensi panel solar cell 50 WP. Dari data hasil pengujian di Tabel 1, 2, dan 3 akan dilakukan pengolahan data untuk mendapatkan nilai daya output dan efisiensi panel solar cell 50 WP seperti pada Tabel 4, 5, dan 6. 
Tabel 4. Hasil Pengolahan Data Sudut $0^{\circ}$

\begin{tabular}{ccccc}
$\begin{array}{c}\text { Waktu } \\
\text { Pengukuran }\end{array}$ & $\begin{array}{c}\text { Radiasi } \\
\text { Mataha } \\
\text { ri }\end{array}$ & $\begin{array}{c}\text { Daya } \\
\text { Input }\end{array}$ & $\begin{array}{c}\text { Daya } \\
\text { outpu } \\
\mathrm{t}\end{array}$ & $\begin{array}{c}\text { Efisie } \\
\text { nsi }\end{array}$ \\
\hline Jam & $\mathrm{W} / \mathrm{m}^{2}$ & Watt & Watt & $\eta(\%)$ \\
\hline $9: 00$ & 582 & 20.952 & 9.216 & 43.986 \\
\hline $10: 00$ & 792 & 28.512 & 9.435 & 33.090 \\
\hline $11: 00$ & 1102 & 39.672 & 9.659 & 24.346 \\
\hline $12: 00$ & 1460 & 52.56 & 9.878 & 18.795 \\
\hline $13: 00$ & 1331 & 47.916 & 9.458 & 19.738 \\
\hline $14: 00$ & 1043 & 52.56 & 9.234 & 24.641 \\
\hline $15: 00$ & 688 & 24.768 & 9.024 & 36.436 \\
\hline $16: 00$ & 548 & 19.728 & 8.802 & 44.617 \\
\hline
\end{tabular}

Tabel 5. Hasil Pengolahan Data Sudut $8^{\circ}$

\begin{tabular}{|c|c|c|c|c|}
\hline $\begin{array}{c}\text { Waktu } \\
\text { Pengukura } \\
\text { n } \\
\end{array}$ & $\begin{array}{c}\text { Radiasi } \\
\text { Mataha } \\
\text { ri }\end{array}$ & $\begin{array}{l}\text { Daya } \\
\text { Input }\end{array}$ & $\begin{array}{c}\text { Daya } \\
\text { Output }\end{array}$ & $\begin{array}{c}\text { Efisie } \\
\text { nsi }\end{array}$ \\
\hline Jam & $\mathrm{W} / \mathrm{m}^{2}$ & Watt & Watt & $\eta(\%)$ \\
\hline 9:00 & 582 & 20.952 & 9.439 & 45.052 \\
\hline 10:00 & 792 & 28.512 & 9.663 & 33.892 \\
\hline 11:00 & 1102 & 39.672 & 9.893 & 24.936 \\
\hline $12: 00$ & 1460 & 52.56 & 10.109 & 19.233 \\
\hline $13: 00$ & 1331 & 47.916 & 9.898 & 20.656 \\
\hline $14: 00$ & 1043 & 37.548 & 9.467 & 25.213 \\
\hline $15: 00$ & 688 & 24.768 & 9.234 & 37.282 \\
\hline $16: 00$ & 548 & 19.728 & 9.011 & 45.677 \\
\hline
\end{tabular}

Tabel 6. Hasil Pengolahan Data Sudut $16^{\circ}$

\begin{tabular}{ccccc}
$\begin{array}{c}\text { Waktu } \\
\text { Penguku } \\
\text { ran }\end{array}$ & $\begin{array}{c}\text { Radiasi } \\
\text { Matahari }\end{array}$ & $\begin{array}{c}\text { Daya } \\
\text { Input }\end{array}$ & $\begin{array}{c}\text { Daya } \\
\text { Output }\end{array}$ & $\begin{array}{c}\text { Efisie } \\
\text { nsi }\end{array}$ \\
\hline Jam & W/m² & Watt & Watt & $\eta(\%)$ \\
\hline $9: 00$ & 582 & 20.952 & 9.654 & 46.076 \\
\hline $10: 00$ & 792 & 28.512 & 9.878 & 34.646 \\
\hline $11: 00$ & 1102 & 39.672 & 10.104 & 25.468 \\
\hline $12: 00$ & 1460 & 52.56 & 10.330 & 19.654 \\
\hline $13: 00$ & 1331 & 47.916 & 10.114 & 21.107 \\
\hline $14: 00$ & 1043 & 37.548 & 9.687 & 25.798 \\
\hline $15: 00$ & 688 & 24.768 & 9.453 & 38.166 \\
\hline $16: 00$ & 548 & 19.728 & 9.239 & 46.829 \\
\hline & & & & \\
\hline
\end{tabular}

Dari hasil pengolahan data kemudian dilakukan pembahasan dan analisa hasil penelitian untuk mendapatkan grafik daya output dan efisiensi panel solar cell $50 \mathrm{WP}$ dengan variasi sudut kemiringan panel solar cell $0^{\circ}, 8^{\circ}$, dan $16^{\circ}$ seperti ditunjukkan pada gambar 4 .

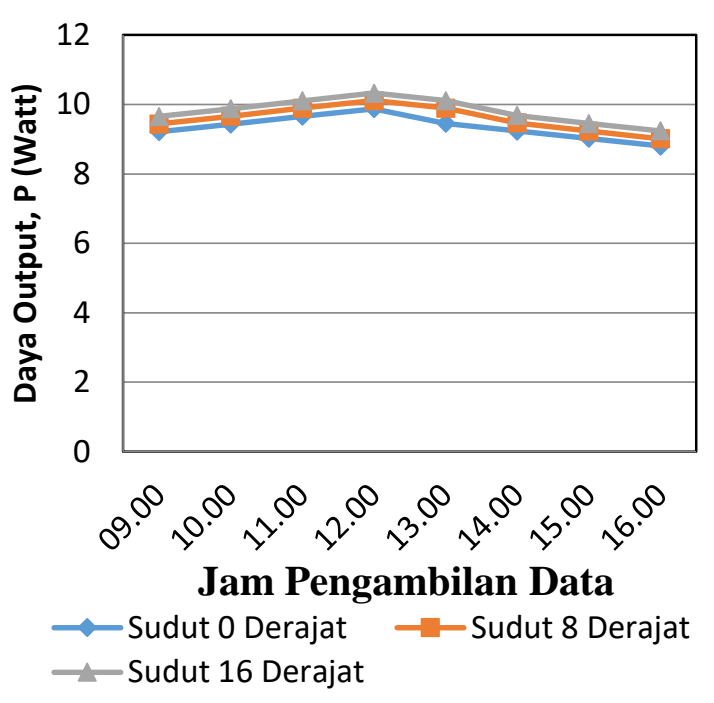

Gambar 4. Hubungan antara daya output dan jam pengambilan data pada ketiga variasi sudut kemiringan

Secara keseluruhan dari gambar 4 dapat dilihat bahwa daya keluaran panel 50 WP tertinggi terjadi pada sudut kemiringan $16^{\circ}$ dan pada jam 12:00 dengan nilai sebesar 10,330 Watt, kemudian yang kedua terjadi pada sudut kemiringan $8^{\circ}$ dan pada jam 12:00, dengan nilai sebesar 10,109 Watt, dan daya terendah terjadi pada sudut kemiringan $0^{\circ}$ dan pada jam 12:00 dengan nilai sebesar 9,878 Watt.

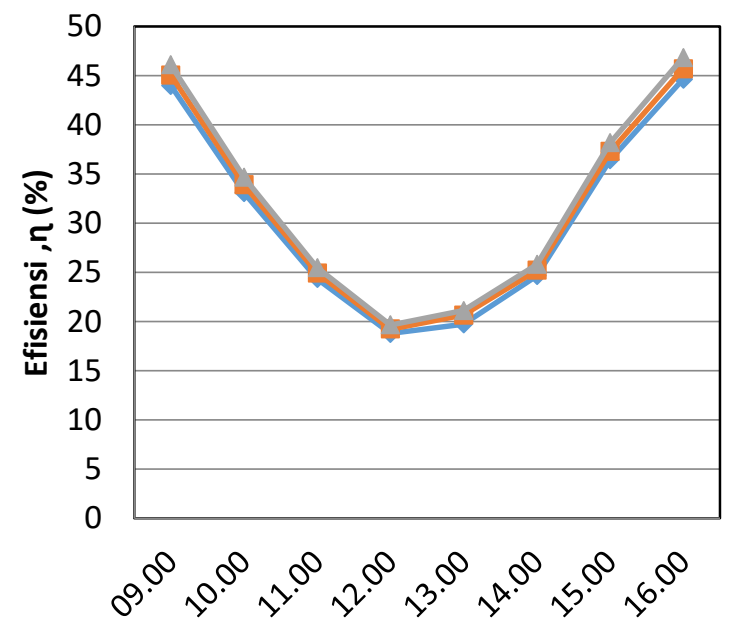

Jam Pengambilan Data

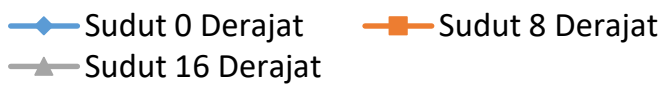

Gambar 5. Hubungan antara efisiensi dan jam pengambilan data pada ketiga variasi sudut kemiringan 
Secara keseluruhan dari gambar 5 dapat dilihat bahwa efisiensi tertinggi terjadi pada sudut kemiringan $16^{\circ}$ dan pada jam 09:00 dengan nilai sebesar 46.076 \%, kemudian yang kedua terjadi pada sudut kemiringan $8^{\circ}$ dan pada jam 09:00 dengan nilai sebesar $45.052 \%$, kemudian efisiensi terendah terjadi pada sudut kemiringan $0^{\circ}$ dan pada jam 09:00 dengan nilai sebesar $43.986 \%$

\section{Kesimpulan}

Dari hasil pengujian instalasi pembangkit listrik tenaga surya kapasitas 50 WP dapat diambil kesimpulan bahwa efisiensi tertinggi terjadi pada sudut kemiringan $16^{\circ}$ dan pada jam 09:00 dengan nilai sebesar $46.076 \%$, kemudian yang kedua terjadi pada sudut kemiringan $8^{\circ}$ dan pada jam 09:00 dengan nilai sebesar $45.052 \%$, kemudian efisiensi terendah terjadi pada sudut kemiringan $0^{\circ}$ dan pada jam 09:00 dengan nilai sebesar 43.986\%.

\section{Referensi}

[1]. Sodiqin. A dan Yani. A. 2016, Analisa charging time sistem solar cell menggunakan pencari arah sinar matahari yang dilengkapi dengan pemfokus cahaya. Jurnal turbo program studi Teknik Mesin Universitas Muhammadyah Metro Lampung. Volume 5 No. 1 Juni 2016

[2]. Samsurizal; Makkulau. A \& Christion. 2018, Analisis Pengaruh Sudut Kemiringan Terhadap Arus Keluaran Pada Photovoltaic Dengan Menggunakan Regretion Quadratic Method. Jurnal Energi \& Kelistrikan Vol. 10, No. 2, September 2018.

[3]. Yani. A. 2016, Pengaruh Penambahan Alat Pencari Arah Sinar Matahari Dan Lensa Cembung Terhadap Daya Output Solar Cell. Turbo: Jurnal program studi Teknik Mesin Universitas Muhammadyah Metro Lampung. Volume 5 No. 2 Desember 2016
[4]. Tamimi. S; Indrasari. W; \& Iswanto. B. H. 2016, Optimasi Sudut Kemiringan Panel Surya Pada Prototipe Sistem Penjejak Matahari Aktif. Seminar Nasional Fisika 2016 Prodi Pendidikan Fisika dan Fisika, Fakultas MIPA, Universitas Negeri Jakarta

[5]. Ikhsan, 2013, Peningkatan Suhu Modul Dan Daya Keluaran Panel Surya Dengan Menggunakan Reflektor, Jurnal ilmiah Dosen pada Jurusan Fisika Fakultas Sains dan Teknologi UIN Alauddin Makassar.

[6]. Sumbung, F.H. dan Letsoin, Y, 2012, analisa dan estimasi radiasi konstan energi matahari melalui Variasi sudut panel fotovoltaik shs 50 WP. Jurnal Ilmiah Mustek Anim. 